\title{
ABIOTIC FACTORS INFLUENCING MANTANGAN (Merremia peltata) INVASION IN BUKIT BARISAN SELATAN NATIONAL PARK
}

\author{
JANI MASTER ${ }^{1 *}$, SOEKISMAN TJITRO SOEDIRDJO ${ }^{2}$ and IBNUL QAYIM ${ }^{3}$ \\ ${ }^{1}$ Department of Bidogy, Faailty of MathematicsandNatural Saienes \\ Universitas Lampung BandarLampung35145, Indonesia \\ ${ }^{2}$ Weed SaenceSocity of Indonesia \\ ${ }^{3}$ Department of Bidogy, Faailty of MathematicsandNatural Sciences \\ Insitut Petanian Bogr, Bogr 16680, Indonesia
}

Received 20 January 2015/ Accepted 27 January 2016

\begin{abstract}
Some areas in Bukit Barisan Selatan National Park have serious problems related to Merema pdtata (Family Convolvulaceae) invasion. The abiotic factors influencing $\mathrm{M}$ pdtata invasion were investigated in this study. This research compared abiotic factors in three forest locations with different invasion levels i.e. severe, moderate and mild invasions. Abiotic factors measured were percentage of tree canopy coverage, micro climate factors (temperature and humidity), elevation above sea level and physical and chemical properties of the soil surface. In this study, canopy coverage is classified as abiotic factors because it influences the intensity of light that can reach the forest floor. A posthoc D uncan's Multiple Range Test (DMRT) was employed to determine significant differences ( $\mathrm{p}<0.05)$ among abiotic factors. In addition, a test of correlation and multiple linear regression were conducted to determine the relationships between abiotic factors and $\mathrm{M}$. pdtatainvasion. Multiple regression testing showed that canopy coverage significantly $(\mathrm{p}<0.05)$ influenced M pdtatainvasion. Based on the generated model, a $1 \%$ addition of canopy coverage would decrease $\mathrm{M}$ pdtata invasion by $2.8 \%$. Multiple linear regression analysis was used to predict the relationship between soil nutrients and invasion. The $\mathrm{C} / \mathrm{N}$ ratio and $\mathrm{P}_{2} \mathrm{O}_{5}, \mathrm{Ca}, \mathrm{Mg}$ and $\mathrm{Na}$ concentration significantly $(\mathrm{p}<0.05)$ influenced invasion level. Again, based on the generated model, the increase in the $\mathrm{C} / \mathrm{N}$ ratio as well as in $\mathrm{P}_{2} \mathrm{O}_{5}$ and $\mathrm{Ca}$ concentrations were correlated with the reduction of $\mathrm{M}$ pdtata invasion; while the increase of $\mathrm{Mg}$ and $\mathrm{Na}$ concentrations were correlated with the increase of $\mathrm{M}$ pdtata invasion. M pdtatainvasion in Bukit Barisan Selatan National Park was influenced by opened forest canopy and was correlated with high concentration of Na and Mg in the soil of theinvaded forestareas.
\end{abstract}

Keywords: Bukit Barisan Selatan National Park, invasive species, mantangan, Meremiapdtata

\section{INTRODUCTION}

Indonesia is a country with abundant flora and fauna, some of which are conserved and protected in conservation areas such as national parks. Existing national park areas in Indonesia are threatened by alien plant species that invade and threaten flora and fauna biodiversity.

Alien species that have the ability to grow quickly so as to impact biodiversity in invaded areas can be referred to as Invasive Alien Species (IAS) (Pyšek \& Richardson 2010). Broadly, an IAS is a species that has the potential to harm the

\footnotetext{
*Corresponding author:j.janter@ gmail.com
}

economy, environment and/ or cause damage to human, animal or plant health (National Invasive Species Council 2006).

Meremia patata or mantangan in the local language, is an invasive species of conservation areas. This species causes severe problems in Bukit Barisan Selatan National Park (BBSNP) with more than 7,000 ha covered by $\mathrm{M}$. pettata (Master $\&$ al. 2013). Infestation of the weed is suspected to be the cause of animal migrations, such as tiger, elephant and Sumateran rhinoceros, to rural areas up north (Irianto \& Tjitrosoedirdjo 2010). Analysis of Landsat and Advanced Land O bserving Satellite (ALO S) images indicated that $M$ petata invasion is found from south part of 
BBSNP running $33 \mathrm{~km}$ to the north of the national park. It is also found in small outbreaks as far as $50 \mathrm{~km}$ north of BBSNP (Master $\notin a l .2$ 2013).

The BBSNP is the third biggest conservation area in Sumatera Island covering an area of 356,800 ha. Administratively, this area belongs to Lampung Barat, Pesisir Barat and Tanggamus Districts of Lampung Province and the Bengkulu District of Bengkulu Province, (4 $4^{0} 31^{1}-5^{0} 57^{\prime} \mathrm{S}$; $103^{0} 34^{\prime}-104^{\circ} 43^{\prime}$ E) (G aveaua etal. 2007).

M pdtata is a liana (climbing plant) of the Convolvulaceae family (Paynter $\mathrm{kal}$. 2006), and it is distributed throughout Madagascar, the Mescarenes, Seychelles, Malay Peninsula, Malaya Islands, Philippines, New Guinea, Northern Australia and throughout Polynesia (O oststroom \& Hoogland 1953). It is similar to sweet potato in morphology, with a wide heart shaped leaf connected by peltate petiole, in contrast to the petiole connection of sweet potato. The hairless plant stem grows to $20 \mathrm{~m}$ in length and excretes white liquid when injured. It may grow over other plants (Stone 1970). The corolla is white or yellow, 5-6 cm in length and forms a bell-shape corolla (Fosberg \& Sachet 1977). Spreading of this plant occurs generatively, both by seeds or vegetatively from roots along its stems which touch the ground. Vegetative growth rates can reach $16 \mathrm{~cm} /$ week (Pengembara 2014).
Environmental factors, both biotic and abiotic, determine the presence of a species in a particular location (Huang \& al. 2003). Accordingly, not all alien species introduced to an area will become invasive; this can be influenced by factors including environmental fitness and the presence or absence of predators or competitors (Theoharides \& D ukes 2007). The rapid growth of M pdtata in BBSNP is probably caused by a number of abiotic factors. The objective of this research was to determine abiotic factors influencing M. pdtatainvasion in BBSNP.

\section{MATERIALS AND METHODS}

Menemia pettata is found mostly in southern regions of BBSNP, but not all of M petatain this region grows densely. To determine abiotic factors influencing plant invasion, environmental factors were recorded in three forest locations with different invasion levels, i.e. severely invaded, moderately invaded and mildly invaded forest (Fig. 1). First location (severely invaded forest) is close to the village enclave Way Haru, Bandar D alam and Tampang. Based on land cover maps, this site has a decreasing forest cover for an area of 2,565.54 ha from 2000 to 2009. Presumably these changes were the result of forest clearing

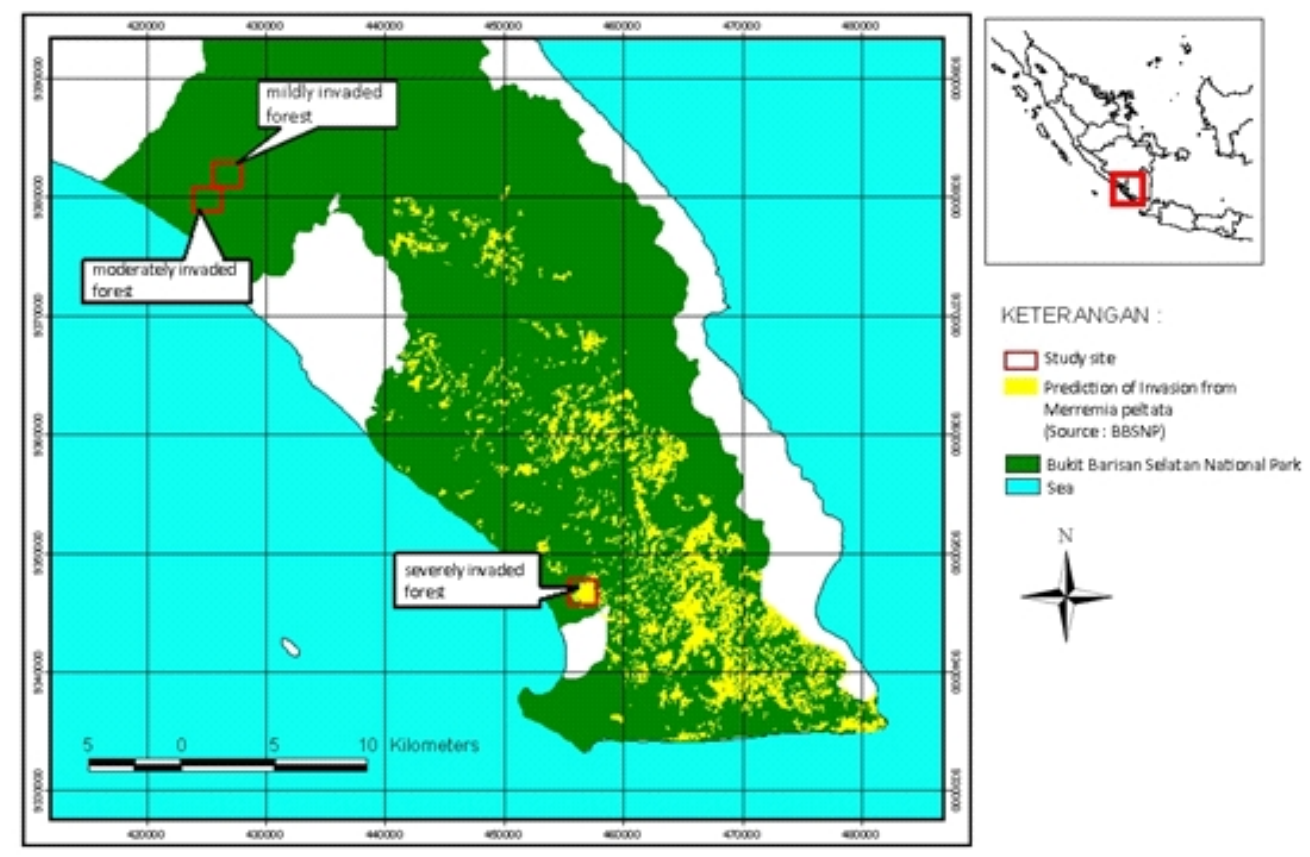

Figure 1 Map of research location of M. pdtata invasion in Bukit Barisan Selatan National Park, Lampung, Sumatera (Master \&al. 2013) 
for plantations (Prasetyo eal. 2011). The second location (moderately invaded forest) is a post-fire forest in 1997; fires that occurred mostly on the forest floor affecting the lining of plant and open up some forest canopy (WCS-IP 2001). The third location (mildly invaded forest) is a primary forest. Selection and classification of these invasion levels were based on coverage of $\mathrm{M}$ pdtatafrom Landsat and ALOS image analyses in 2002 and 2008 (Master $\notin$ al. 2013). The final selection was conducted by recording the percentage of $\mathrm{M}$. pdtatacanopy coverage by using plot of $20 \times 20 \mathrm{~m}$ area.

Three line transects of $1,000 \mathrm{~m}$ each, with minimum of $200 \mathrm{~m}$ interval distance between each line transect, were made in each forest location. Plots of $20 \times 20 \mathrm{~m}$ were sampled along each line transect, at $100 \mathrm{~m}$ intervals, thus totaling 30 plots in each location. M pdtata invasion was estimated based on the percentage of plot that was covered by M pdtata. Environmental factors recorded for each plot were: 1 . the percentage of tree canopy coverage (tree canopies that were more than $4 \mathrm{~m}$ in height) which was estimated using a concave densiometer; 2 . microclimate (temperature and humidity) were measured at noon, $1 \mathrm{~m}$ above the ground using thermometer and hygrometer on each plot; 3. elevation above sea level; and 4. physical and chemical properties of top soil using composite method (Crozier $\mathrm{eal}$. 1998). Soil physical and chemical properties observed were soil texture, $\mathrm{pH}\left(\mathrm{H}_{2} \mathrm{O}\right), \mathrm{KCl}, \mathrm{C}$ organic, N-Kjedahl, Cation Exchange Capacity (CEC) and exchangeable cations ( $\mathrm{K}, \mathrm{Na}, \mathrm{Ca}, \mathrm{Mg})$. Soil texture fraction comparisons were separated as follows: 1 . sand fraction having particles with diameter of $2 \mathrm{~mm}$ - 50 ; 2. loam fraction having particles with diameter of $50 \mu-2 \mu$; and 3. clay fraction having particles with diameter of $<2 \mu$ ) (Hardjowigeno 2010).
D ata for each environmental factor from each of the three locations were analyzed using ANOVA and the mean differences were tested using the D uncan's Multiple Range Test (DMRT) at $\mathrm{p}<0.05)$. Tests of correlation and linear regression were carried out using SPSS 12 program to determine any relationships existed between abiotic factors and $\mathrm{M}$ pdtatainvasion.

\section{RESULT S AND DISCUSSION}

\section{Percentage Cover of $M$. peltata Invading Forests}

The mean coverage percentage of $M$ pdtatain the mildly invaded forest ranged from 1 to $15 \%$. In comparison, the mean coverage percentage in the moderate invaded forest ranged from 27 to $55 \%$. In the severe invaded forest, the mean coverage percentage was $44 \%$, while in some location the percentage wasup to $100 \%$.

\section{Abiotic Factors (non-soil) and M. peltata Invasion Levels}

Of the six abiotic factors observed i.e. air temperature, air humidity, ground temperature, soil humidity, soil $\mathrm{pH}$ and percentage of tree canopy coverage (canopy above $4 \mathrm{~m}$ ), only the percentage of tree canopy coverage was significantly varied $(p<0.05)$ among the three locations (Table 1). Forest canopy coverage had significant negative correlation to $\mathrm{M}$. pdtata invasion. Based on a generated model, every $1 \%$ addition of canopy coverage would decrease $\mathrm{M}$. pdtatainvasion by $2.8 \%$ (Table 2 ).

The severely invaded forest locations had more open tree canopy coverage. The open canopies facilitate access of M. pdtata to solar radiation such that the weed dominated these

Table 1 Summary of abiotic factors at the three research locations

\begin{tabular}{lcccccc}
\hline Location & $\begin{array}{c}\text { Air temperature } \\
\left({ }^{\circ} \mathrm{C}\right)\end{array}$ & $\begin{array}{c}\text { Air } \\
\text { humidity } \\
(\%)\end{array}$ & $\begin{array}{c}\text { Ground } \\
\text { temperature } \\
\left({ }^{\circ} \mathrm{C}\right)\end{array}$ & $\begin{array}{c}\text { Soil humidity } \\
(\%)\end{array}$ & Soil pH & $\begin{array}{c}\text { Canopy } \\
\text { coverage } \\
(\%)\end{array}$ \\
\hline $\begin{array}{l}\text { Mildly invaded forest } \\
\text { Moderately invaded }\end{array}$ & $26.41 \mathrm{a}$ & $90.72 \mathrm{a}$ & $25.65 \mathrm{a}$ & $47.93 \mathrm{a}$ & $6.75 \mathrm{a}$ & $92.31 \mathrm{a}$ \\
$\begin{array}{l}\text { forest } \\
\text { Severely invaded }\end{array}$ & $27.93 \mathrm{~b}$ & $83.79 \mathrm{~b}$ & $26.10 \mathrm{~b}$ & $47.65 \mathrm{a}$ & $6.65 \mathrm{a}$ & $81.51 \mathrm{~b}$ \\
forest & $27.15 \mathrm{ab}$ & $88.84 \mathrm{a}$ & $26.00 \mathrm{ab}$ & $54.05 \mathrm{a}$ & $6.51 \mathrm{a}$ & $69.89 \mathrm{c}$ \\
\hline
\end{tabular}

Note: Numbers followed by the same letters in same columns are not significantly different $(p<0.05)$ 
Table2 Results of multiple linear regression between percentages of M pdtatacoverage and abiotic factors Coefficients $^{\mathrm{a}}$

\begin{tabular}{|c|c|c|c|c|c|c|c|c|}
\hline & \multirow{2}{*}{ Model } & \multicolumn{2}{|c|}{ Unstandardized coefficients } & \multirow{2}{*}{$\begin{array}{c}\begin{array}{c}\text { Standardized } \\
\text { coefficients }\end{array} \\
\text { Beta }\end{array}$} & \multirow[t]{2}{*}{$\mathrm{t}$} & \multirow[t]{2}{*}{ Sig. } & \multicolumn{2}{|c|}{ Collinearity statistics } \\
\hline & & B & $\begin{array}{l}\text { Std. } \\
\text { Error }\end{array}$ & & & & Tolerance & VIF \\
\hline \multirow[t]{7}{*}{1} & (Constant) & 89.020 & 53.253 & & 1.672 & 0.099 & & \\
\hline & Air temperature & -2.841 & 3.189 & -0.148 & -0.891 & 0.376 & 0.356 & 2.812 \\
\hline & Air humidity & -2.782 & 1.668 & -0.281 & -1.668 & 0.100 & 0.345 & 2.897 \\
\hline & Ground temperature & 6.209 & 7.892 & 0.119 & 0.787 & 0.434 & 0.432 & 2.317 \\
\hline & Soil humidity & -0.603 & 0.386 & -0.236 & -1.562 & 0.123 & 0.431 & 2.320 \\
\hline & Soil pH & -23.790 & 8.175 & -0.448 & -2.910 & 0.005 & 0.414 & 2.418 \\
\hline & Canopy coverage & -1.218 & 0.301 & -0.427 & -4.047 & 0.000 & 0.882 & 1.134 \\
\hline
\end{tabular}

Note: $\mathrm{a}=$ Dependent Variable: percentage of M pdtata coverage

areas. In the mildly invaded forest, mean canopy coverage was denser $(92.31 \%)$. D enser canopy coverage prevented extensive M pdtata growth and development such that it only grew through gaps of canopy where there were collapsed trees. This result is consistent with other findings which reported that M pdtata grew on the edges of forest, especially in degraded land in Fiji (Kirkham 2005), and that this plant grew densely in logged forest and open forest in other parts of Sumatera (Irianto \& Tjitrosoedirdjo 2010).

Air temperature, air humidity and ground temperatures were all significantly ( $\mathrm{p}<0.05)$ higher in moderately invaded forest than in mildly invaded forest (Table 1). The increase in these factors was most likely related to tree canopy coverage, such that more open canopies would increase solar radiation, air and ground temperatures, as well as rainfall reaching the forest floor(Sasaki \& Mori 1981).

Severely invaded forest had more open tree canopy coverage, but air temperature, air humidity and ground temperatures in that location were not different to mildly invaded forest. This is probably because the ground coverage of M pdtata in both levels of invaded forest produced similar microclimate.

There were no relationship between elevation above sea level and the infestation size of M. patata. This is despite the fact that M pdtatais known to occupy lowland habitats to $300-400 \mathrm{~m}$ above sea level in Samoa and Fiji (Meyer 2000, Kirkham 2005).

\section{Soil Abiotic Factors and M. peltata Invasion Levels}

Beside the aforementioned environmental factors, the physical and chemical properties of the soil were also analyzed in the three research locations. The mildly invaded forest was dominated with a sandy-clay-loam soil texture, while the moderately and severely invaded forest had clay and clay-loam soil texture(Table3).

Soil in the secondary and invaded forests had higher clay content than soil in the primary forest. The clay fraction is the most important

Table 3 Soil texture samples in the three research locations

\begin{tabular}{lcc}
\hline Location & Texture & Percentage (\%) \\
\hline Mildly invaded forest & sandy clay loam & 33.33 \\
& clay & 55.56 \\
& clay loam & 11.11 \\
\hline Moderately invaded forest & clay & 44.44 \\
& clay loam & 55.56 \\
\hline Severely invaded forest & clay & 55.56 \\
& clay loam & 44.44 \\
\hline
\end{tabular}


Table 4 Average soil chemical properties in three research locations

\begin{tabular}{|c|c|c|c|c|c|c|}
\hline \multirow{2}{*}{ Soil chemical property } & \multicolumn{2}{|c|}{ Mildly invaded forest } & \multicolumn{2}{|c|}{ Moderately invaded forest } & \multicolumn{2}{|c|}{ Severely invaded forest } \\
\hline & Value & Level & Value & Level & Value & Level \\
\hline C-organic (\%) & $2.07 \mathrm{a}$ & Middle & $2.62 \mathrm{ab}$ & Middle & $3.46 \mathrm{~b}$ & High \\
\hline $\mathrm{N}(\%)$ & $0.17 \mathrm{a}$ & Low & $0.21 \mathrm{a}$ & Middle & $0.35 \mathrm{~b}$ & Middle \\
\hline C/ N Ratio & $11.66 \mathrm{a}$ & Middle & $11.88 \mathrm{a}$ & Middle & $9.88 \mathrm{~b}$ & Low \\
\hline $\mathrm{P}_{2} \mathrm{O}_{5}(\mathrm{mg} / 100 \mathrm{~g})$ & $24.22 \mathrm{a}$ & Middle & $18.44 \mathrm{~b}$ & Low & $24.88 \mathrm{a}$ & Middle \\
\hline $\mathrm{K}_{2} \mathrm{O}(\mathrm{mg} / 100 \mathrm{~g})$ & $28.33 \mathrm{a}$ & Middle & $31.11 \mathrm{a}$ & Middle & 39.77 a & Middle \\
\hline P-Bray (ppm) & $4.00 \mathrm{a}$ & Very Low & $2.76 \mathrm{a}$ & Very Low & $6.53 \mathrm{~b}$ & Very Low \\
\hline $\mathrm{Ca}\left(\mathrm{cmol}_{d} \mathrm{~kg}\right)$ & $4.59 \mathrm{a}$ & Low & $5.50 \mathrm{a}$ & Low & $11.11 \mathrm{~b}$ & Middle \\
\hline $\mathrm{Mg}\left(\mathrm{cmol}_{\mathrm{d}} / \mathrm{kg}\right)$ & $3.04 \mathrm{a}$ & High & $3.96 \mathrm{a}$ & High & $6.28 \mathrm{~b}$ & High \\
\hline $\mathrm{K}\left(\mathrm{cmol}_{\mathrm{d}} \mathrm{kg}\right)$ & $0.57 \mathrm{a}$ & Middle & $0.50 \mathrm{a}$ & Middle & $0.67 \mathrm{a}$ & High \\
\hline $\mathrm{Na}\left(\mathrm{cmol}_{d} \mathrm{~kg}\right)$ & $0.41 \mathrm{a}$ & Middle & $0.46 \mathrm{~b}$ & Middle & $0.51 \mathrm{c}$ & Middle \\
\hline $\mathrm{CEC}^{*}\left(\mathrm{cmol}_{\mathrm{d}} \mathrm{kg}\right)$ & $13.51 \mathrm{a}$ & Low & $19.07 \mathrm{a}$ & Middle & $25.67 \mathrm{~b}$ & High \\
\hline Base saturation (\%) & $62.55 \mathrm{a}$ & High & $55.11 \mathrm{ab}$ & High & $71.11 \mathrm{~b}$ & High \\
\hline
\end{tabular}

Notes: $\mathrm{CEC}=$ Cation ExchangeCapacity

Numbers followed by the sameletters in the samerow are not significantly different $(p<0.05)$

component because its particles have more surface area than sand particles. Soil with higher clay content has higher Cation Exchange Capacity (CEC) than sandy soil due to greater overall surfacearea of clay particles (Munawar 2011). The CEC value was higher in the severely invaded forest $(25.67 \mathrm{cmol} / \mathrm{kg})$, followed by moderately invaded forest $(19.07 \mathrm{cmol} / \mathrm{kg})$, with the lowest in the mildly invaded forest $(13.51 \mathrm{cmol} / \mathrm{kg}$ ) (Table 4). The CEC is a chemical property closely related to soil fertility. Soil with higher organic and clay contents had higher CEC values than soil with low organic content and/or sandy soils (Hardjowigeno 2010).

Further, soil with higher $\mathrm{CEC}$ values is able to better retain and provides nutrients (cations and anions) than soil with low CEC values. Thelack of cation exchange capacity in low CEC soil results in the nutrients being easily washed through the soil with underground water movement (infiltration, percolation) such that these nutrients are no longer available for plant growth.

The severely invaded forest had a higher alkaline density (base saturation) value $(71.11 \%)$ than the other two forest locations. Contributing to this higher alkaline density were the alkaline cations $\mathrm{Ca}, \mathrm{Mg}, \mathrm{K}$ and $\mathrm{Na}$. These alkaline cations areimportant soil nutrients required by plants.

The presence of organic substances in the soil can improve soil fertility chemically, physically and biologically. The amount of organic carbon in the severely invaded forest was higher (3.46\%) than that in the mildly invaded forest. Based on soil fertility criteria, C-organic in the severely invaded forest belonged to high category.

Nitrogen $(\mathrm{N})$ is a crucial soil nutrient, often found with low availability. Total nitrogen in the severely invaded forest was significantly $(\mathrm{p}<0.05)$ higher $(0.35 \%)$ than that in the other two locations. There was no significant difference ( $p$ 0.05) of total nitrogen between the mildly invaded forest $(0.17 \%)$ and the moderately invaded forest $(0.21 \%)$. Higher nitrogen values contribute to low $\mathrm{C} / \mathrm{N}$ ratios such that more nitrogen is available to microorganisms to decompose carbon containing material, recycling the nitrogen quickly (Munawar 2011). Higher nitrogen contents in plants will result in faster vegetative growth. $\mathrm{M}$ pdtata was rarely found to flower in severely invaded forest, and this may have been caused by high nitrogen contents in the soil.

\section{Regression Analyses between Soil Factors and M. peltata Invasion}

D ouble linear regression analyses were conducted to predict whether soil nutrient status was correlated with invasion. $\mathrm{C} / \mathrm{N}$ ratio and concentration of $\mathrm{P}_{2} \mathrm{O}_{5}, \mathrm{Ca}, \mathrm{Mg}$ and $\mathrm{Na}$ significantly $(p<0.05)$ contributed to M pdtata invasion (Table 5). Based on a generated model, the increase of $\mathrm{C} / \mathrm{N}$ ratio and concentration of $\mathrm{P}_{2} \mathrm{O}_{5}$ and Ca may reduce $\mathrm{M}$ pdtatainvasion; while the increase of $\mathrm{Mg}$ and $\mathrm{Na}$ concentration may increase M pdtatainvasion. M pdtatainvasion in the severely invaded forest was correlated with 
Table5 Result of multiple linear regression between the percentage of M pdtatacoverageand soil nutrientfactors Coefficients $^{\mathrm{a}}$

\begin{tabular}{|c|c|c|c|c|c|c|c|c|}
\hline & \multirow{2}{*}{ Model } & \multicolumn{2}{|c|}{ Unstandardized coefficients } & \multirow{2}{*}{$\begin{array}{c}\text { Standardized } \\
\text { coefficients }\end{array}$} & \multirow{2}{*}{$\mathrm{t}$} & \multirow{2}{*}{ Sig. } & \multicolumn{2}{|c|}{ Collinearity statistics } \\
\hline & & B & $\begin{array}{c}\text { Std. } \\
\text { Error }\end{array}$ & & & & Tolerance & VIF \\
\hline \multirow[t]{10}{*}{1} & (Constant) & 50.768 & 144.015 & & 0.353 & 0.729 & & \\
\hline & Loam & 0.797 & 1.181 & 0.117 & 0.675 & 0.509 & 0.315 & 3.173 \\
\hline & Clay & -0.569 & 0.905 & -0.140 & -0.629 & 0.538 & 0.190 & 5.277 \\
\hline & $\mathrm{H}_{2} \mathrm{O}$ & -11.183 & 23.641 & -0.128 & -0.473 & 0.642 & 0.128 & 7.818 \\
\hline & CN Ratio & -8.535 & 2.739 & -0.370 & -3.116 & 0.006 & 0.668 & 1.498 \\
\hline & $\mathrm{P}_{2} \mathrm{O}_{5}$ & -2.721 & 1.197 & -0.377 & -2.273 & 0.036 & 0.342 & 2.924 \\
\hline & $\mathrm{Ca}$ & -5.902 & 1.694 & -0.888 & -3.485 & 0.003 & 0.145 & 6.899 \\
\hline & $\mathrm{Mg}$ & 18.726 & 4.721 & 0.970 & 3.966 & 0.001 & 0.157 & 6.351 \\
\hline & $\mathrm{Na}$ & 210.264 & 74.615 & 0.390 & 2.818 & 0.012 & 0.493 & 2.029 \\
\hline & $\begin{array}{l}\text { Base } \\
\text { saturation (\%) }\end{array}$ & 0.735 & 0.459 & 0.292 & 1.601 & 0.128 & 0.284 & 3.522 \\
\hline
\end{tabular}

Note: $\mathrm{a}=$ D ependent Variable: coverage of Meremia pdtata

low $\mathrm{C} / \mathrm{N}$ ratios and high concentration of $\mathrm{Mg}$ and Nain the soil.

Sodium has an important role in determining soil characteristics and plant growth, especially in areas close to a beach. The severely invaded forest in this study is located close to a beach. This is a suspected cause of the high $\mathrm{Na}$ content in the soil in this location. Excessive Na content can also be toxic for plants (Hanafiah 2007), influencing cell membrane and organelle functions, as well as disrupting plant metabolism sequences (Hamim 2008). Soil sodium concentrations significantly ( $p<0.05)$ increased as invasion levels of $\mathrm{M}$ pdtata increased in this study. This weed is suspected of being a halophyte, being able to grow in a land with high salt content.

Another soil nutrient correlated with M. pdtata invasion was Mg. Soil samples from the severely invaded forest had significant $(p<0.05)$ higher content of $\mathrm{Mg}(6.28 \mathrm{cmol} / \mathrm{kg})$ than either mildly invaded forest $(3.04 \mathrm{cmol} / \mathrm{kg})$ or moderately invaded forest $\left(3.96 \mathrm{cmol}_{\mathrm{d}} \mathrm{kg}\right)$ (Table 4). Magnesium is a crucial element used in chlorophyll formation. Like other soil nutrients, magnesium deficiency results in a typical color change to leaf material. Premature leaf fall is also caused by magnesium deficiency (Hanafiah 2007). Magnesium is a macro element in soil when found in its organic form (Sutcliffe \& Baker 1975) and has important role in phosphate availability (Agustina 2004).

\section{CONCLUSIONS}

A biotic factors influencing $M$ pdtatainvasion in Bukit Barisan Selatan National Park are opened forest canopy coverage and high content of $\mathrm{Na}$ and Mgin the soil.

\section{ACKNOWLEDGEMENTS}

This study was part of Master thesis of the first author, financially supported by SEAMEOBIOTROP DIPA 2011. The author thanked Artha Graha Peduli and Wildlife Conservation Society Indonesia Program for their assistance in conducting the field work.

\section{REFERENCES}

Agustina L. 2004. Dasar-dasar Nutris Tanaman Jakarta (ID ): PT Rineka Cipta.

Crozier CR, Heiniger RW. 1998. Sal Fads Sail Sampingfor Preision Faming Systems North Carolina (USA): North Carolina StateUniversity.

Fosberg FR, Sachet MH. 1977. Flora of Micronesia, part 3, Convolvulaceae. Contributii Botanice 36:1-34.

Gaveaua DLA, Wandono H, Setiabudi F. 2007. Three decades of deforestation in southwest Sumatera: Have protected areas halted forest loss and logging, and promoted re-growth. Biol Conserv 134:495504. 
Hamim. 2008. Fisidog Tumbuhan Jakarta (ID): Universitas Terbuka.

Hanafiah KA. 2007. Dasar-dasar lmi Tanah Jakarta (ID): PT. Raja G rafindo Persada.

Hardjowigeno S. 2010. IlmuTamah Jakarta (ID ): Akademika Pressindo.

Huang W, Pohjonen V, Johansson S, Nashanda M, Katigula MIL, Luukkanen O. 2003. Species Diversity, Forest Structure and Species Composition in Tanzania Tropical Forest. For Ecol Manage 173:11-24.

Irianto R, Tjitrosoedirdjo S. 2010. Invasi Meremiapdtata(L.) Merr., Convolvulaceae di Taman Nasional Bukit Barisan Selatan, Indonesia. Journal Gulma dan Tumbuhan Invasi Tropika 1:65-70.

Kirkham WS. 2005. Valuing invasives: Understanding the Meremia pdtata invasion in Post-Colonial Samoa. Dissetation Austin (USA): The University of Texas atAustin.

Master J, Tjitrosoedirdjo SS, Q ayim I, Tjitrosoedirdjo S. 2013. Ecological Impact of Meremia pdtata (L.) Merrill Invasion on Plant Diversity at Bukit Barisan Selatan National Park. Biotropia 20(1):29-37.

MeyerJY. 2000. Preliminary review of the invasive plants in the Pacific islands. In: Sherley G, editor. Invasive Speeiesin thePadific A Techical ReiewandDraftReginal Strategy. Samoa (WS): South Pacific Regional EnvironmentProgramme. p 85-114.

Munawar A. 2011. Kesuburan Tamah dan Nutris Tanaman Bogor(ID):IPB Press.

National Invasive Species Council. 2006. Invasive Speies Definition Clanification and Guidance White Paper. https:/ / www.invasivespeciesinfo.gov/ docs/ council / isacdef.pdf (accessed O ctober $20^{\text {th }}$, 2014).
O oststroom van SJ, Hoogland RD. 1953. Convolvulaceae. Flora Malesiana I 4:452-3.

Paynter Q, Harman H, Waipara N. 2006. Prospects for biological control of Meremia pdtata. Report New Zealand:Conservation International.

Pyšek P, Richardson DM. 2010. Invasive species, environmental change and management and health. Ann Rev Environ Resour 35: 25-55.

Pengembara T, Master J, Yulianty, Rustiati EL, Subiakto A. 2014. Laju pertumbuhan mantangan (Meremia pdtata L. Merr.) yang tumbuh melalui regenerasi vegetatif. Proceedings of Seminar Nasional Pengembangan Teknologi Pertanian. Lampung (ID ): Politeknik Negeri Unila.

Prasetyo A, Hikmat A, Prasetyo LB. 2011. Pendugaan Perubahan Cadangan Karbon di Tambling Wildlife Conservation Taman Nasional Bukit Barisan Selatan. Media Konservasi 16: 87 - 91.

Sasaki S, Mori T. 1981. Growth responses of Dipterocarp seedlingsto light. Malaysian Forester 44: 319-45.

Stone BC. 1970. Theflora of Guam. Micronesica6:1-659.

Sutcliffe JF, Baker DA. 1975. PlantandMineal Salts London (UK): Edward Arnold Publishing.

Theoharides KA, Dukes JF. 2007. Plant invasion across space and time: factors affecting non indigenous species success during four stages of invasion. J New Phytol 176:256-73.

Wildlife Conservation Society - Indonesia Program (WCSIP). 2001. Taman Nasional Bukit Barisan Selatan dalam ruang dan waktu. Research Report Bogor (ID): PHKA/ WCS-IP. 